\title{
PENCEGAHAN DAMPAK NEGATIF PERKEMBANGAN TEKNOLOGI INFORMASI TERHADAP PENGGUNA INTERNET
}

\author{
Oleh: \\ Indriati Amarini \\ Fakultas Hukum Universitas Muhammadiyah Purwokerto \\ E-mail: indriatiamarini@ump.ac.id
}

\begin{abstract}
Abstrak
Tulisan ini menguraikan perkembangannya teknologi yang mendasari suatu tipe baru sistem budaya yang mengatur kembali keseluruhan dunia sosial sebagai objek kontrol. Teknologi bukan sekedar bermakna akan tetapi telah menjadi suatu lingkungan dan suatu jalan hidup dan ini merupakan dampak yang substantif (substantif impact). Internet merupakan simbol material embrio masyarakat global yang menawarkan ruang baru yaitu cyberspace realitas baru yaitu realitas virtual, komunitas baru yaitu virtual community. Dalam rangka mencegah cyber crime tidak cukup hanya melalui pengaturan melalui undang-undang. Hal ini dikarenakan penggunaan hukum pidana dalam penanggulangan kejahatan hanya merupakan kurieren am symptom. Hal ini dikarenakan hukum pidana hanya merupakan pengobatan simptomatik dan bukan pengobatan kausatif. Berkaitan dengan perkembangan ilmu pengetahuan dan teknologi yang menimbulkan permasalahan di bidang hukum, aparat penegak hukum yaitu hakim dapat menggunakan kekuasaan yang luas sebagai judge made law.
\end{abstract}

Kata kunci: Dampak Negatif; Teknologi Informasi, Pengguna Internet

\section{A. PENDAHULUAN}

Hukum, teknologi informasi dan globalisasi merupakan tiga bidang yang saling terkait. Hal ini dikarenakan perkembangan teknologi yang sangat cepat beserta penyebaran produk-produknya dimungkinkan karena adanya globalisasi dan dampaknya terasa pula di bidang hukum. ${ }^{1}$ Globalisasi informasi ${ }^{2}$ adalah suatu fenomena khusus dalam peradaban manusia yang bergerak terus dalam masyarakat global dan merupakan bagian dari proses manusia global. Adapun makna globalisasi dari pespektif aliran cyberspace globalists yaitu Featherstone ${ }^{3}$ mengemukakan bahwa globalisasi ditandai dengan tumbuhnya perkembangan

\footnotetext{
Agus Raharjo, 2008, Model Hibrida Hukum Cyberspace (Studi tentang Model Pengaturan di Indonesia, Ringkasan Disertasi, Program Doktor IImu Hukum Universitas Diponegoro Semarang, hlm. 11.

2 Adanya globalisasi informasi merupakan salah satu pertimbangan yang digunakan pembuat Undang-undang Nomor 11 Tahun 2008 tentang Informasi dan Transaksi Elektronik, dimana negara Indonesia sebagai bagian dari masyarakat inormasi dunia.

3 Dalam Wasisto Raharjo Jati, 2013, Pengantar Kajian Globalisasi Analisa Teori dan Dampaknya di Dunia Ketiga, Mitra Wacana Media, Jakarta, hlm. 27.
} 
teknologi informasi mutakhir maupun penemuan lainnya sehingga memungkinkan manusia untuk menjalankan fungsinya lebih cepat dan mudah.

Munculnya cyberspace telah mengubah tatanan dunia. Persoalan sosial kemanusiaan, ekonomi, politik, kesehatan, sains dan teknologi dijalin menjadi sebuah network (jaringan) dan tidak bersifat sektoral, setiap aspek kehidupan saling berinteraksi, berkorelasi dan saling berpengaruh dalam jaring kehidupan yang disebut sebagai sebuah Titik Omega: Kesadaran Semesta Digital. Dengan demikian, globalisasi informasi menyentuh seluruh aspek penting kehidupan yaitu bidang politik, sosial, budaya, hokum, dan sebagainya..

Perubahan yang terjadi sebagai akibat dari globalisasi informasi melalui media internet dapat terlihat dengan jelas khususnya generasi muda yang disebut dengan digital natives, multitasker atau generasi Z. Generasi Z yang merupakan penguasa telatah dunia maya yang mengisi ruang publik di media sosial dengan berbagai komentar pedas, lekas dan bergegas. Saat belajar membaca dan menulis serta beranjak remaja disekitar mereka ada MP3 Player, game online hingga media sosial. Generasi ini dibesarkan oleh orang tua dengan penuh perhatian dan kehati-hatian. Ketika masih bayi, mobil yang digunakan ditulisi stiker Baby on Board. Apapun yang diinginkan anak akan berusaha dipenuhi oleh orang tua. Sebagai anak kandung media sosial, mereka merespons apa saja yang sedang terjadi. ${ }^{4}$ William J. Schroer menggambarkan generasi $X$ secara global sebagai lost generation.

Generasi Z sebagaimana diuraikan di atas, menjadi raja di jagat maya. Mereka misalnya bisa dengan pedas mem-bully politikus yang tidak becus memimpin. Sebaliknya mereka bisa dengan lekas memuja politikus yang mereka sukai tanpa pretense politik. Mereka bergegas berpindah dari satu isu ke isu lain dengan riangnya. Selain itu ciri generasi $Z$ adalah spontan bereaksi menanggapi situasi. Di media sosial, muncul kampanye dukungan terhadap kasus hukum Prita, Kampanye kasus Jogja Ora Didol. Kampanye ini makin menguat ketika Muhammad Arif Buwono (17) yang merupakan representasi generasi Z ditangkap aparat pemerintah saat menebalkan mural bertuliskan Jogja Ora Didol.

4 Amir Sodikin dan Wisnu Nugroho, 2014, "Generasi Lekas dan Bergegas" dalam Tinjauan Kompas 2014 Tantangan, Prospek Politk dan Ekonomi Indonesia, Kompas Media Nusantara, Jakarta, hlm.142 
Pengaruh globalisasi informasi dari penggunaan internet sangat luar biasa dalam segala bidang. Pengaruh atau dampak zona baru dalam kehidupan manusia atau "zona mabuk teknologi" bisa positif dan negatif atau bagaikan "pisau bermata dunia". Selain itu internet juga merupakan sumber dari berbagai macam kejahatan di dunia cyber "cybercrime" seperti pornografi, kekerasan, penipuan, carding (transaksi memakai kartu kredit), perjudian dan sebagainya. Berdasarkan uraian tersebut maka dapat dianalisis mengenai apa alasannya perkembangan teknologi informasi menimbulkan permasalahan hokum. Selain itu, bagaimana cara mencegah dampak negatif perkembangan teknologi informasi melalui prinsip pertanggungjawaban pidana.

\section{B. PEMBAHASAN}

1. Permasalahan Hukum Sebagai Akibat Perkembangan Teknologi Informasi

Teknologi telekomunikasi dan teknologi komputer "dikawinkan" dan "melahirkan" suatu benda pintar yang bernama internet maka sejak saat itu pula manusia mulai berfikir dan berbuat melampaui batas-batas tradisional yang ada dalam pikiran dan teritorialnya. Cara berpikir yang tanpa batas (the borderless way of thinking) dan keengganan untuk berurusan dengan birokrasi yang berbelit-belit (smash the boundaries, tar down the hierarchy and dismantle the bureaucracy) menjadi ciri dari cara berpikir dan berbuat penggila internet. Pada akhirnya internet menjadi simbol atau lambang kemajuan sekaligus peradaban.Internet menawarkan berbagai keunggulan, kemudahan, harapan, kesenangan dan kesempatan. Selain itu media internet sebagai hasil teknologi yang merupakan sumber dari maraknya akivitas illegal di dunia maya.

Perkembangan teknologi informasi menimbulkan permasalahan hukum sehingga memunculkan pengaturan hukum siber (cyber law) atau teknologi informasi (Law of Information Technology) atau hukum dunia maya (virtual world law) atau hukum mayantara. Secara luas cyber law bukan hanya

5 John Nasibitt, Nana Naisbitt dan Douglas Philips, High Tech, High Touch, Pencarian Makna di Tengah Perkembangan Pesat Teknologi dikutip dari Agus Rahardjo, "Pencegahan Cybercrime Melalui Pengembangan Prinsip Pertanggungjawaban Pidana Bagi Pengguna Internet" dalam seminar Membangun Sistem Hukum Pidana Berbasis Budaya Hukum Nasional, FH UNSOED, Purwokerto, 29 Juni 2013, hlm. 4. 
meliputi tindak kejahatan di internet, namun juga aturan yang melindungi para pelaku e-commerce, e-learning, pemegang hak cipta, rahasia dagang, paten, e-signature dan masih banyak lainnya. Dengan kata lain, aplikasi internet sesungguhnya memiliki aspek hukum meliputi aspek hak cipta, aspek merek dagang, aspek fitnah, pencemaran nama baik dan aspek privasi.

Ada beberapa pendekatan atau teori untuk menggambarkan hubungan antara teknologi dan hukum. Pertama, pendekatan Teori Instrumental, Cockfield \& Priedmore $^{6}$ melihat bahwa teknologi adalah teknologi (technology is technology) yaitu alat yang dikembangkan secara rasional untuk memenuhi kebutuhan tertentu. Teknologi dikembangkan dengan prinsip rasionalitas dan efisiensi.Teknologi menghadirkan atau memberikan pilihanpilihan dan kebutuhan-kebutuhan yang rasional bagi masyarakat. Oleh karena itu teknologi bersifat netral (tidak bersifat baik dan buruk) dan terpisah dari proses ekonomi, politik, sosial dan budaya. Produktivitasnya dapat diukur secara objektif terlepas dari budaya, sehingga teknologi dapat diterapkan secara universal. Dalam hal terjadi penyalahgunaan teknologi, teori instrumental melihat bahwa "guns don't kill people-people kill people". Pihak yang harus dipersalahkan adalah orang yang menyalahgunakan teknologi dan bukan teknologi itu sendiri, maka internet adalah alat atau perkakas yang siap untuk melayani tujuan dari para pemakainya.Teknologi dianggap netral, tanpa penilaian isi dari teknologi itu sendiri.Teknologi tidak ada hubungannya dengan baik atau buruk dan dapat digunakan oleh siapapun. ${ }^{7}$

Kedua: pendekatan atau Teori Substantif yang melihat bahwa teknologi tidak netral karena teknologi berkaitan erat dengan kepentingan dari subjek yang membuat teknologi tersebut. Sejarah perkembangan teknologi komputer dan internet pada awalnya untuk memenuhi kebutuhan perang. Oleh karena itu, teknologi dapat menjadi sesuatu alat yang berbahaya karena pembuat teknologi dapat mengontrol atau mendominasi orang atau masyarakat yang menggunakan teknologi melalui teknologi yang dibuatnya. Lebih dari itu teknologi memberi dampak bagi masyarakat baik yang sesuai dengan tujuan

J. Sitompul, Bagaimana Mengatur Cyberspace?, http://warungcyber.web.id./?p=143, diakses Senin 7 Juli 2014.

7 Andrew Feenberg, Critical Theory of Technologi, dikutip dari Agus Rahardjo, "Pencegahan Cybercrime Melalui Pengembangan Prinsip Pertanggungjawaban Pidana Bagi Pengguna Internet' dalam Agus Rahardjo, Op.Cit., hlm. 5 
maupun di luar tujuan pembuatan teknologi. Teknologi telah membatasi kebebasan manusia karena manusia semakin tergantung dengan teknologi dan teknologi bukanlah manusia yang memiliki kebebasan dan makhluk otonom. ${ }^{8}$

Penilaian terkait pandangan tentang teknologi (termasuk internet) datang juga dari pemikiran Elull dan Heidegger yang berpendapat bahwa teknologi mendasari suatu tipe baru sistem budaya yang mengatur kembali keseluruhan dunia sosial sebagai objek kontrol. Teknologi bukan sekedar bermakna akan tetapi telah menjadi suatu lingkungan dan suatu jalan hidup dan ini merupakan dampak yang substantif (substantif impact). Internet merupakan simbol material embrio masyarakat global yang menawarkan ruang baru yaitu cyberspace realitas baru yaitu realitas virtual, komunitas baru yaitu virtual community. ${ }^{9}$

Pendekatan teori instrumentalis dan pendekatan teori substantif dapat diterapkan dalam pembuatan kebijakan atau regulasi.Teori instrumentalis memberikan pendekatan yang konservatif, kaku dan melihat ke belakang (backward-looking) dalam pembuatan kebijakan atau regulasi.Pendekatan ini disebut pendekatan teknologi adalah hukum (technology adalah hukum). Menurut teori instrumental, perkembangan teknologi harus dilihat secara netral dan terpisah dari kepentingan politik, sosial dan budaya. Dengan demikian pendekatan dengan menggunakan teori ini akan menekankan kebutuhan untuk mengikuti hukum yang telah ada dengan menjaga konsistensi dan kepastian hukum dalam rangka menjaga nilai dan kepentingan masyarakat. Pembuat kebijakan atau regulasi akan berusaha keras untuk mengidentifikasikan kepentingan atau nilai baru yang timbul akibat perkembangan teknologi. Masalah yang muncul adalah ketika pembuat kebijakan tidak berhasil mengidentifikasi dan hal ini akan menimbulkan kekosongan hukum. Selain itu, mengutamakan pendekatan ini akan mengakibatkan hukum selalu tertinggal di belakang dan tidak dapat mensejajarkan posisi sesuai dengan perkembangan teknologi.

\footnotetext{
Ibid., Ibid., hlm. 6.
} 
Sedangkan pendekatan substantif memberikan pendekatan yang fleksibel, liberal dan melihat ke depan (forward-looking) dalam pembentukan kebijakan atau regulasi. Pendekatan ini disebut sebagai pendekatan hukum adalah teknologi (law is technology). Perkembangan teknologi tidak terpisahkan dari proses ekonomi, politik dan sosial. Oleh karena itu kebijakan atau regulasi perlu disesuaikan dengan perkembangan teknologi. Perubahan kebijakan sesuai dengan perkembangan teknologi merupakan upaya untuk menjaga kepentingan atau nilai masyarakat yang juga berkembang seiring dengan penerapan teknologi baru. Melalui pendekatan ini, pembuat kebijakan atau regulasi melihat kebutuhan untuk mentransformasi hukum dengan menerapkan metode atau cara pandang baru sesuai dengan perkembangan teknologi yang ada. Kelemahan pendekatan ini adalah prinsip-prinsip hukum yang telah ada dapat menjadi rusak dan tidak konsisten lagi. Selain itu hukum yang mengikuti perkembangan teknologi akan cepat berubah berakibat kepada semakin besarnya ketidakpastian hukum.

2. Pencegahan Dampak Negatif Perkembangan Teknologi Informasi Terhadap Pengguna Internet Melalui Prinsip Pertanggungjawaban Pidana

Akhir abad ke-20 memasuki awal millennium, dunia dikejutkan oleh banyaknya temuan baru dalam bidang sains monumental diantaranya teori kuantum modern, teori relativistik juga teori chaos dan fraktal. Teori-teori tersebut telah mengubah cara pandang manusia tentang alam semesta. Segala sesuatu yang awalnya dianggap sangat jelas dan pasti berubah secara total. Sementara itu perkembangan teknologi telah memicu lahirnya realitas artificial (buatan) yang disebut cyberspace. Munculnya cyberspace telah mengubah makna tatanan dunia. Persoalan sosial kemanusiaan, ekonomi, politik, kesehatan, sains, dan teknologi dijalin menjadi sebuah network (jaringan) dan tidak bersifat sektoral, setiap aspek kehidupan saling berinteraksi, berkorelasi dan saling berpengaruh dalam sebuah jaring kehidupan. Dengan kata lain cyberspace telah mengubah makna realitas yang dipahami selama ini tidak saja dalam makna simbolik tetapi juga makna realitas materialnya misalnya makna masyarakat, interaksi sosial, komunikasi, budaya dan lain sebagainya. 
Perkembangan signifikan terjadi pula pada ilmu hukum, sebagai raksi terhadap pandangan sistem-mekanik-formal-legalistik yang dibangun positivisme hukum diantaranya teori chaos dalam hukum. ${ }^{10}$ Teori chaos mengatakan, teori hukum yang harus dipahami sebagai teori sistem-mekanis (menurut pandangan positivism hukum) jelas merupakan kekeliruan yaitu kekeliruan sejak awal memotret realitas hukum. Menurut Charles Stampford, kaum positivism hukum telah memaksakan model pendekatan yang digunakan dalam ilmu kealaman terhadap ilmu-ilmu sosial, sehingga terjadi reduksi realitas yang luar biasa. Dalam teori chaos realitas hukum harus dipahami, dihayati dan dimaknai secara mendalam karena hanya melalui cara tersebut, realitas hukum yang sesungguhnya dapat diungkap. ${ }^{11}$

Sistem hukum juga tidak akan mungkin secara mutlak menutup diri terhadap perubahan-perubahan di dalam masyarakat. Sebagaimana diungkapkan Arnold M. Rose ${ }^{12}$ bahwa ada 3 teori umum tentang sebab utama terjadinya perubahan-perubahan yang terjadi pada masyarakat adalah: a. kumulasi yang progresif daripada penemuan-penemuan di bidang teknologi;

b. kontak atau konflik antara kebudyaan;

c. gerakan social.

Dengan demikian, proses cybernation dalam jagat raya cyberspace menimbulkan harapan akan kemudahan, kesenangan dan kesempatan ternyata tidak selamanya demikian. Hal ini dikarenakan dalam cyberspace juga terdapat persoalan hukum yang muncul seperti cybercrime dengan berbagai macam bentuknya.

Sebagaimana diungkapkan NazurabAbdul Manap yang membedakan tipe-tipe cyber crime menjadi 3 (tiga) yaitu:

a. cyber crime against meliputi theft berupa theft of information, theft of propoery dan theft of services, fraud/cheating, forgery dan mischief;

10 Lihat dalam: Anthon F. Susanto, 2010, IImu Hukum Non Sistematik Fondasi Filsafat Pengembangan IImu Hukum, Yogyakarta, Genta Publishing, hlm. 9.

Ibid., hlm. 11.

12 Ibid., hlm. 95. 
b. cyber crimes against persons, meliputi pornografi, cyberharassment, cyber stalking dan cyber-trespass. Cyber-trespass meliputi spam e-mail, hacking a web page dan breaking into personal computer;

c. cyber-terrorism ${ }^{13}$

Adapun ruang lingkup cyber law ${ }^{14}$ adalah sebagai berikut.

a. Hak cipta (copy right).

b. Hak merek (trade mark).

c. Pencemaran nama baik (defamation).

d. Fitnah, penistaan, penghinaan (hate speech).

e. Serangan terhadap fasilitas komputer (hacking, viruses, illegal acces).

f. Pengaturan sumber daya internet seperti IP address domein name, dan lain-lain.

g. Kenyamanan individu (privacy).

h. Prinsip kehati-hatian (duty care).

i. Tindakan kriminal biasa yang menggunakan TI sebagai alat.

j. Isu prosedural seperti yurisdiksi, pembuktian, penyidikan, dan lain-lain.

k. Kontrak/transaksi elektronik dan tanda tangan digital.

I. Pornografi termasuk pornografi anak.

m. Pencurian melalui internet.

n. Perlindungan konsumen.

o. Pemanfaatan internet dalam aktivitas keseharian manusia seperti $e$ commerce, e-government, e-education dan sebagainya.

Teknologi informasi memungkinkan setiap orang dimanapun dapat melakukan hubungan hukum dengan orang lain. Perkembangan tersebut memerlukan hukum untuk mengatur perilaku manusia, memecahkan masalahmasalah yang muncul dan menjadi pedoman dalam bertingkah laku. Hukum sendiri dituntut untuk dapat mengikuti perkembangan jaman. Akan tetapi muncul persoalan kecepatan yang dimiliki hukum tak sebanding dengan kecepatan teknologi informasi itu sendiri. Kesan selanjutnya yang muncul adalah hukum selalu tertinggal dalam mengatur aktivitas perilaku manusia.

${ }^{13}$ Sebagaimana dikutip dari D.Y. Witanto, Problematika Penanganan Cyber Crime dalam Perspektif Asas Teritorial di Indonesia, Varia Peradilan No. 321, Agustus 2012, hlm. 74.

14 Ibid., hlm. 75. 
Ketertinggalan hukum bukan merupakan indikasi bahwa hukum termarginalisasi akan tetapi ada beberapa hal yang menyebabkannya. Pertama, perbedaan kepentingan dan kemauan politik dari badan pembuat hukum merupakan kendala yang tidak mudah untuk dicarikan titik temunya. Kedua, proses pembuatan undang-undang (dari aspek prosedur) membutuhkan waktu yang tidak sedikit padahal perkembangan teknologi berkembang sangat cepat sehingga dengan proses yang demikian lama menyebabkan hukum yang terbentuk menjadi usang dari sisi teknologinya. Ketiga, hukum memerlukan kepastian dan ketepatan (dari aspek substansi atau materi yang hendak diatur) sehingga membuat hukum yang memiliki sifat yang demikian bukanlah pekerjaan yang mudah.

Sebagaimana telah diuraikan dalam bahasan sebelumnya bahwa ada dua pendekatan atau teori yang berkaitan dengan pengaturan hukum tentang dunia siber yang virtual (cyberspace) yaitu teori instrumental dan teori substantif. Langdon Winner berpendapat bahwa internet ialah milik bersama sehingga setiap orang memiliki hak penuhuntuk berada di dalam dunia siber, termasuk berinteraksi di dalamnya. Oleh karena itu, pemerintah tidak perlu campur tangan dengan membuat regulasi yang membatasi kebebasan mereka. Bahkan teknologi akan berkembang apabila pemerintah tidak mengontrol teknologi dan apabila halangan-halangan terhadap free market competition dihilangkan.

Namun pada kenyataannya masyarakat yang ada di dunia virtual adalah masyarakat yang berasal dari dunia nyata. Masyarakat mempunyai nilai dan kepentingan baik secara sendiri-sendiri maupun bersama-sama yang harus dilindungi. Karakteristik internet yang borderless dan ubiquitous serta transaksi yang dapat dilakukan secara anonim membutuhkan pengaturan. Selain itu walaupun terjadi di duania virtual, transaksi yang dilakukan masyarakat memiliki pengaruh dalam dunia nyata baik secara ekonomis maupun non ekonomis. Hak dan kewajiban seseorang dapat berpindah secara elektronik melalui internet.

Dalam rangka pencegahan cybercrime, pemerintah bereaksi dengan membuat peraturan perundang-undangan dengan mengkriminalisasi 
cybercrime yaitu Undang-undang Nomor 11 Tahun 2008 tentang Informasi dan Transaksi Elektronik. Namun undang-undang ini masih banyak kelemahan terutama dengan sifatnya sebagai umbrella act sehingga tidak dapat menjangkau cybercrime yang bersifat baru dan detail. ${ }^{15}$ Masih diperlukan pengaturan yang lebih detail dan spesifik untuk memudahkan aparat penegak hukum menggunakan atau mengaplikasikan ketika berhadapan dengan cybercrime.

Terkait dengan pembentukan dan perubahan hukum terhadap cyber crime yang akan dilaksanakan di Indonesia, terdapat perbedaan pendapat ahli hukum di Indonesia. Ada pakar hukum pidana yang tidak setuju terhadap rumusan baru tentang kejahatan yang dilakukan oleh cyber crime sebab rumusan itu akan sia-sia sebab akan selalu ketinggalan zaman karena cepatnya perkembangan teknologi dewasa ini. Sementara itu peraturan perundang-undangan yang lama (tradisional) masih dapat dipergunakan, oleh karena itu perlu menghemat energi dalam menyusun peraturan baru tersebut. Sementara itu para ahli hukum pidana yang lain mengatakan bahwa dalam menghadapi cyber crime ini, pemerintah harus segera membuat peraturan perundang-undangan baru yang khusus dengan mempertimbangkan tata urutan yang telah berlaku secara internasional. ${ }^{16}$

Indonesia masih menyamakan dan menganalogikan jenis cybercrime itu ke dalam bentuk kejahatan tradisional. Kedua jenis kejahatan ini memiliki perbedaan yang cukup signifikan baik cara maupun dampak yang ditimbulkan. Sebagaimana diungkapkan Brenner bahwa : First, though it is carried out by a small percentage of the poulayion of a society (or of the word, since for surpassing what they could achieve in the real-world where one-to-one victimization and serial crimesare the norm. Consequently, the number of cybercrimes will exponentially exceed real-world crimes. Second, cybercrime is additional to the real-world crime with which law enforcement must continue to deal; peope will still rape, rob and murder. These two factors combine to create an overload; law enforcement's ability to react to cybercrime erodes because the resources that were minimally adequate to deal with realworld

\footnotetext{
${ }_{15}$ Agus Raharjo, Pencegahan Cybercrime..., Op.Cit., hlm. 8.

16 Ibid.
} 
crime alone are totally inadequate to deal with cybercrime and real-word crime in combination. ${ }^{17}$

Permasalahan cybercrime tidak bisa didekati melalui pendekatan kriminalisasi saja atau menggunakanpendekatan model reaktif (crime control model) melalui peradilan pidana dan dilakukan oleh polisi. Model ini tidak cukup efektif untuk mencegah cybercrime. Hal ini dikarenakan karakteristik internet dimana bukti fisik mudah hilang atau mudah hancur. Dengan kata lain penggunaan aktivitas formal (affirmative model) tidak cocok untuk menangani cybercrime.

Hal inipun terjadi apabila menggunakan due process model. Hal ini dikarenakan model ini menekankan pada kekuasaan yang dominan adalah kekuasaan yudikatif dan selalu mengacu pada konstitusi. Model ini cocok untuk kepastian hukum akan tetapi tidak cocok untuk mencegah penyalahgunaan internet secara illegal dimana jenis kejahatan ini memiliki kecepatan dan mobilitas yang tinggi.

Model pencegahan penyalahgunaan internet untuk aktivitas illegal yang dikembangkan adalah model pencegahan cybercrime dengan berbasis pada pengguna internet sendiri (prevention based by user). Dengan demikian tumpuan dalam mencegah cybercrime bukan pada pemerintah, polisi, peradilan, akan tetapi pada pengguna internet. Model ini lebih mengandalkan rasa tanggung jawab bagi dirinya sendiri dan lebih luas lagi bagi masyarakat akan rasa aman menggunakan internet.

Selain perlu kerjasama efektif yang harus dilakukan secara intern dalam negara masing-masing, diperlukan juga kerjasama antar negara. Hal ini sejalan dengan perkembangan dunia hokum Internasional dalam mencegah cybercrime. Salah satunya rekomendasi PBB dalam konggres ke VIII (Eight Conggress on Prevention of Crime and Treatment of Offenders) yang membahas perkembangan industri informasi Internasional sebagai berikut.

17 Susan W. Brenner, "Distributed Secutity: Moving Away from Reactive Law Enforcement" dikutip dari Agus Rahardjo, Makalah dalam seminar Membangun Sistem Hukum Pidana Berbasis Budaya Hukum Nasional, FH UNSOED, Purwokerto, 29 Juni 2013, hlm. 8. 
a. Menghimbau negara anggota untuk mengintensifkan upaya-upaya preventif dalam menanggulangi penyalahgunaan komputer dengan tindakan sebagai berikut.

1) Melakukan modernisasi hukum pidana formil maupun materiil.

2) Tindakan pencegahan dan pengamanan computer.

3) Meningkatkan kepekaan warga masyarakat dan aparat penegak hukun terhadap pentingnya pencegahan kejahatan computer.

4) Training atau pelatihan bagi penegak hukum, khususnya mendalami kejahatan ekonomi dan computer crime.

5) Dalam kerangka edukasi, etika penggunaan komputer menjadi kurikulum bidang studi informatika (rules of ethic).

6) Mengadopsi kebijakan perlindungan korban kejahatan komputer (victim protection) sera menyadari pentingnya korban untuk melapor.

b. Para negara anggota untuk berpartisipasi aktif dalam forum internasional yang menyangkut pencegahan kejahatan computer.

c. Merekomendasikan pada Committee on Crime Prevention Control (CCPC) yang merupakan unit PBB untuk melakukan diseminasi membantu negara anggota dalam menghadapi kejahatan komputer. Mempertimbangkan kasus kejahatan komputer dalam hal mengimplementasikan perjanjian ekstradisi di bidang cybercrime. ${ }^{18}$

Dalam rangka mencegah cyber crime tidak cukup hanya satu model pencegahan, akan tetapi diperlukan beberapa macam model pencegahan. Sebagaimana pendapat Barda Nawawi Arief ${ }^{19}$ bahwa penggunaan hukum pidana dalam penanggulangan kejahatan hanya merupakan kurieren am symptom. Hal ini dikarenakan hukum pidana hanya merupakan pengobatan simptomatik dan bukan pengobatan kausatif. Dengan demikian penggunaan beberapa macam model penanggulangan kejahatan dapat mengatasi keterbatasan hukum pidana dalam menanggulangi cybercrime.

Berkaitan dengan perkembangan ilmu pengetahuan dan teknologi yang menimbulkan permasalahan di bidang hukum, aparat penegak hukum yaitu

18 Ade Maman Suherman, 2005, Aspek Hukum dalam Ekonomi Global, Cetakan Kedua, Ghalia Indonesia, Jakarta, hlm. 196

19 Barda Nawawi Arief, 1998, Beberapa Aspek Kebijakan Penegakan dan Pengembangan Hukum Pidana, Citra Aditya Bakti, Bandung, hIm. 47. 
hakim dapat menggunakan kekuasaan yang luas sebagai judge made law. Apabila perundang-undangan tidak mempunyai jawaban dan tidak pula ada putusan pengadilan mengenai perkara yang sejenis yang akan diputuskan maka hakim akan mencari jawabannya pada pendapat sarjana hukum. Jika pendapat ahli hukum tidak diketemukan untuk dijadikan pedoman oleh hakim untuk memutus perkara maka hakim dibenarkan untuk menemukan hukum dengan jalan interpretasi dan konstruksi hukum, kalau perlu mengadakan contra legem terhadap pasal-pasal peraturan perundang-undangan yang telah ada.Dengan demikian hakim dapat menjawab segala masalah hukum baru yang muncul. Dengan kata lain, hakim dituntut aktif (judicial activism) ${ }^{20}$. Hakim harus berperan aktif dalam rangka mewujudkan keadilan sebagai hukum yang hidup dalam masyarakat yang berkembang dinamis.

Karakteristik penyalahgunaan internet tersebut menjadi kondusif untuk melakukan judicial activism. Dalam kondisi dan sistem hukum yang sedemikian ini, sangat perlu dirasakan adanya judicial activism di kalangan para hakim untuk mengisi kekosongan hukum dalam menggapai keadilan dalam masyarakat. Dalam melaksanakan tugas, seorang hakim melalui metode dan berbekal peralatan-peralatan dalam kotak kerja ${ }^{21}$, hakim harus berperan aktif untuk mewujudkan keadilan sebagai hukum yang hidup dalam masyarakat yang berkembang dinamis.

Hakim dalam melaksanakan tugas selain diharapkan lebih aktif atau proaktif $^{22}$ dalam tugas, juga kreatif dan inovatif. Hal ini dikarenakan bahwa hukum berubah dan berkembang tidak terlepas dari dinamika sosial dengan segala kepentingan yang sesungguhnya berada di belakang hukum. Oleh

${ }^{20}$ Lihat Pasal 5 ayat (1) yang berbunyi: Hakim sebagai penegak hukum dan keadilan wajib menggali, mengikuti dan memahami nilai-nilai hukum yang hidup dalam masyarakat.

21 Kotak peralatan kerja yang berisi segala keperluan kerja yang dimiliki, lihat Paulus Efendi Lotulung, 2013, Hukum Tata Usaha Negara Dan Kekuasaan, Salemba Humanika, Yogyakarta, hlm. 101.

22 Istilah hakim harus proaktif didasarkan pada pemikiran realisme dalam ilmu hukum yang meyakini bahwa meskipun hukum adalah sesuatu yang dihasilkan melalui proses yang dapat dipertanggungjawabkan secara logika imperatif namun the life of law has not been logic, it is (socio-psychological) experience. Hakim yang bekerja haruslah "proaktif" membuat putusan untuk menyelesaikan perkara dengan memperhatikan kenyataan-kenyataan sosial. Dengan demikian putusan hakim selalu dapat memenuhi rasa keadilan masyarakat, lihat dalam Sulistyowati Irianto, 2009, Hukum yang Bergerak Tinjauan Antropologi Hukum, Yayasan Obor Indonesia, Jakarta, hlm. 80. 
karena itu tugas hakim menjadi lebih kompleks tidak hanya sekedar penerap undang-undang. Sebagaimana menurut pandangan Klasik yang dikemukakan oleh Montesquieu dan Immanuel Kant bahwa hakim dalam menerapkan undang-undang terhadap peristiwa hukum sesungguhnya tidak menjalankan peranannya secara mandiri. Hakim hanyalah penyambung lidah atau corong undang-undang (bouche de la 10$)^{23}$ sehingga tidak dapat mengubah kekuatan hukum undang-undang, tidak dapat menambah dan tidak pula dapat mengurangi ${ }^{24}$.

Dengan demikian peran aktif dari Hakim dilakukan melalui pertimbanganpertimbangan dalam putusan dalam rangka mewujudkan keadilan sebagai hukum yang hidup dalam masyarakat yang berkembang dinamis. Pelaksanaan judicial activism oleh hakim tersebut dilakukan dengan melakukan penemuan hukum. Penemuan hukum adalah proses konkretisasi atau individualisasi peraturan hukum (das sollen) yang bersifat umum dengan mengingat akan peristiwa konkrit (das sein) tertentu. Hakim selalu dihadapkan pada peristiwa konkrit, konflik atau kasus yang harus diselesaikan atau dipecahan dan untuk dicari hukumnya. Dengan demikian problematik yang berhubungan dengan penemuan hukum pada umumnya melekat pada profesi hakim.Selain itu hasil penemuan hukum oleh hakim merupakan hukum karena mempunyai kekuatan mengikat sebagai hukum karena dituangkan dalam bentuk putusan. Adapun hasil penemuan hukum oleh hakim itu merupakan juga sumber hukum. ${ }^{25}$ Penemuan hukum telah dikenal sejak lama yaitu dimulai abad 19 dengan ajaran penafsiran hukum yang dikenal dengan hermeunitik yuridis. Hermeneutika diartikan sebagai ilmu penafsiran. ${ }^{26}$

Problematik yang berhubungan dengan penemuan hukum pada umumnya terjadi pada profesi hakim. Hal ini dikarenakan setiap hari hakim dihadapkan pada peristiwa konkrit atau konflik untuk diselesaikan. Hasil

3 Lihat dalam Sudikno Mertokusumo, 2014, Penemuan Hukum, Cetakan Kelima, Universitas Atma Jaya, Yogyakarta, hlm. 52.

${ }^{24}$ Sebagaimana pendapat Montesquieu, undang-undang adalah satu-satunya sumber hukum positif. Oleh karena itu demi kepastian hukum, kesatuan hukum serta kebebasan hakim, hakim harus ada di bawah undang-undang, Ibid.

25 Sudikno Mertokusumo, Op.Cit., hlm. 50.

26 Hermeunitika adalah teori tentang bekerjanya pemahaman dalam menafsirkan teks, dalam Paul Ricoeur, 2012, Hermeunitika IImu Sosial, Cetakan Keempat, Kreasi Wacana, Yogyakarta, hlm. 57. Terjemahan dari Paul Ricoeur, 1981, Hermeneutics and the Human Sciences, Cambridge University Press, Penerjemah Muhammad Syukri. 
penemuan hukum oleh hakim merupakan hukum karena mempunyai kekuatan mengikat sebagai hukum karena dituangkan dalam bentuk putusan (judge made law).

Penemuan hukum dikenal dalam dalam praktek peradilan setelah dalam perundang-undangan terutama yang mengatur tentang kekuasaan kehakiman secara substansial mengatur mengenai beberapa ketentuan yang memungkinkan kegiatan penemuan hukum itu dilakukan. Penemuan hukum oleh hakim tidak hanya menyangkut penerapan peraturan-peraturan hukum terhadap peristiiwa konkrit tetapi juga penciptaan hokum dan juga pembentukan hukum. Hakim melakukan penemuan hukum karena dihadapkan pada peristiwa konkrit atau konflik untuk diselesaikan. Hasil penemuan hukum merupakan hukum karena mempunyai kekuatan mengikat yang dituangkan dalam bentuk putusan. Penemuan hukum oleh hakim juga sekaligus merupakan sumber hukum juga. ${ }^{27}$ Hakim dengan kewenangan sebagai judge made law dalam menghadapi kasus-kasus yang terkait dengan informasi dan teknologi.

\section{PENUTUP}

1. Simpulan

Internet sesungguhnya hanya alat dari sebuah hasil teknologi yang kemudian berkembang menjadi sebuah entitas yang yang tidak dapat dikesampingkan dalam kehidupan. Dalam konteks Teori Instrumental maka internet adalah alat atau perkakas yang siap untuk melayani tujuan dari para pemakainya. Teknologi dianggap netral, tanpa penilaian isi dari teknologi itu. Dalam perkembangannya teknologi mendasari suatu tipe baru sistem budaya yang mengatur kembali keseluruhan dunia sosial sebagai objek kontrol. Teknologi bukan sekedar bermakna akan tetapi telah menjadi suatu lingkungan dan suatu jalan hidup dan ini merupakan dampak yang substantif (substantif impact). Internet merupakan simbol material embrio masyarakat global yang menawarkan ruang baru yaitu cyberspace realitas baru yaitu realitas virtual, komunitas baru yaitu virtual community.

\footnotetext{
${ }^{27}$ Bambang Sutiyoso, Op. Cit., hlm. 65.
} 
Dalam rangka mencegah cyber crime tidak cukup hanya melalui pengaturan melalui undang-undang. Hal ini dikarenakan penggunaan hukum pidana dalam penanggulangan kejahatan hanya merupakan kurieren am symptom. Hal ini dikarenakan hukum pidana hanya merupakan pengobatan simptomatik dan bukan pengobatan kausatif. Berkaitan dengan perkembangan ilmu pengetahuan dan teknologi yang menimbulkan permasalahan di bidang hukum, aparat penegak hukum yaitu hakim dapat menggunakan kekuasaan yang luas sebagai judge made law.

2. Rekomendasi

Penanggulangan aktivitas illegal internet tidak cukup menggunakan pendekatan kriminalisasi saja. Perlu ada kerja sama antara pengguna internet (users) pemerintah, aparat penegak hukum, LSM/NGO dan masyarakat secara luas.

\section{DAFTAR PUSTAKA}

\section{Buku}

Arief, Barda Nawawi, 1998, Beberapa Aspek Kebijakan Penegakan dan Pengembangan Hukum Pidana, Citra Aditya Bakti, Bandung.

Irianto, Sulistyowati, 2009, Hukum yang Bergerak Tinjauan Antropologi Hukum, Yayasan Obor Indonesia, Jakarta.

Jati, Wasisto Raharjo, 2013, Pengantar Kajian Globalisasi Analisa Teori dan Dampaknya di Dunia Ketiga, Mitra Wacana Media, Jakarta.

Manan, Abdul, 2013, Aspek-aspek Pengubah Hukum, Kencana Prenada Media Group, Jakarta.

Mertokusumo, Sudikno, 2014, Penemuan Hukum, Cetakan Kelima, Universitas Atma Jaya, Yogyakarta.

Sodikin, Amir dan Nugroho, Wisnu, 2014, Tinjauan Kompas 2014 Tantangan, Prospek Politk dan Ekonomi Indonesia, Kompas Media Nusantara, Jakarta.

Soekanto, Soerjono, 1999, Pokok-Pokok Sosiologi Hukum, Cetakan Kesembilan,: Rajawali Pers, Jakarta.

Suherman, Ade Maman, 2005, Aspek Hukum dalam Ekonomi Global, Ghalia Indonesia, Jakarta. 
Sumantri, Bambang Sigap, 2014, Keserakahan Pasar Merusak Desentralisasi, Tinjauan Kompas, Kompas, Jakarta.

Susanto, Anthon F., 2010, IImu Hukum Non Sistematik Fondasi Filsafat Pengembangan Ilmu Hukum Indonesia, Genta Publishing, Yogyakarta.

Sutiyoso, Bambang, 2012, Metode Penemuan Hukum Upaya Mewujudkan Hukum yang Pasti dan Berkeadilan, UII Press, Yogyakarta.

\section{Sumber Lain}

Raharjo, Agus, 2008, Model Hibrida Hukum Cyberspace (Studi tentang Model Pengaturan di Indonesia), Ringkasan Disertasi, Program Doktor IImu Hukum Universitas Diponegoro Semarang.

Pertanggungiawaban Pidana Bagi Pengguna Internet Seminar Membangun Sistem Hukum Pidana Berbasis Budaya Hukum Nasional, FH UNSOED, Purwokerto, 29 Juni 2013.

Witanto, D.Y., Problematika Penanganan Cyber Crime dalam Perspektif Asas Teritorial Di Indonesia, Varia Peradilan No. 321, Agustus 2012. 